\title{
THE QUALITY OF BUSINESS LEGAL ENVIRONMENT AND ITS RELATION WITH BUSINESS FREEDOM
}

\begin{abstract}
Paulina Nogal-Meger*
Abstract

Background. The legal environment, understood as a set of factors, affects enterprises in a given country and plays a large role in the business environment.

Research aims. The main objective of the conducted research is to verify the hypothesis about the significance of legal environment in relation to the freedom of business conducted and the GDP achieved in a given country.

Methodology. The research objective achievement was based on the analysis of the Rule of Law Index, Economic Freedom Index and Business Freedom (being the EFI subfactor) as well as GDP values for 97 countries that were included in the Rule of Law and Economic Freedom classification in 2016. The comparative method and factor analysis were conducted.

Key findings. The higher level of the rule of law is related to higher economic development and provides wider freedom in business for entrepreneurs. In the studied cases, the leading countries' group which includes Singapore, Australia, New Zealand, Denmark, and Norway, achieved the highest levels of both indexes' values - Rule of Law and Business Freedom in comparison to other countries in analysed population.
\end{abstract}

Keywords: Business environment, legal environment, rule of law, economic freedom.

\section{INTRODUCTION}

A business' environment is considered as all conditions, processes, and institutions that can shape a company's performance, either internally or externally and which are beyond the control of business units. This type of a company's environment has the largest scope and

* University of Gdansk. E-mail: pnogal@ug.edu.pl 
covers all elements that concern a company. It also concerns factors that influence directly, indirectly or that are merely considered to have a potential impact in the future on some aspects of a company's performance. The environment defined as such can be divided into areas of less complexity but with more specified areas of influence in dependence and relationship between entities. One division can include internal and external environment. An internal environment refers to all conditions and factors that occur within a company like financial conditions, research and development, employees, or organisational culture. All actions taken by a company have a direct influence within this area. In turn an external environment refers to all conditions and factors which are located outside a company.

The microenvironment is considered as all conditions influencing a company's actions and development within the market sector. All entities related to a company are located in this area and these are especially competitors, consumers, and suppliers. The broadest and most extensive is the macroenvironment. It is divided into four main fields of similar factors that eventually affect the most important actions taken by a company. These fields of affection are related to factors of political, economic, social, and technological aspects, known also as PEST analysis (Kotler, 2005, pp. 174-179). Since the company's environment is constantly changing, which means that unfamiliar factors appear and have to be taken into account, the PEST analysis has been extended to PESTEL. The latter analysis refers to environmental and legal macro-conditions that have not been considered before.

The analysis will focus on a description of business legal environment, its importance and quality measurement by the World Justice Project (WJP), and the relation between freedom in business and the quality of business legal environment. In this sense the predictability of the legal environment will be considered along with its quality. The main goal of the research is to answer the question whether legal factors, generally understood as the rule of law, affect the freedom of business. The additional goal is to determine whether this impact is significant. At the same time, it was assumed that the freedom of business is wider when the level of economic development in a given country is higher. The values of the World Justice Index, Business Freedom, and GDP value (PPP measured) from 2016 were used in the study. The analysis of the data was based on the comparative method for 
the entire population and a breakdown into country regions. A factor analysis was also applied to identify the relation between the rule of law and the business freedom.

\section{BUSINESS ENVIRONMENT}

Entrepreneurs, suppliers, consumers, competitors, society in general and other entities producing and purchasing - who take various actions on the market, have to cope with forces and factors coming from the macroenvironment. They can be considered as threats or opportunities but the most crucial for a company is to attentively observe, make preparations, when it is possible, react and adjust faster and better than competitors do. It cannot be stated that a company should especially focus on economic forces rather than technological or demographical ones, because one factor can influence more than one environment. The changes occurring in one area frequently affect other areas for example natural environment deterioration forces changes in legislation, technology, economy, and society. All areas are essentially significant and interrelated.

External environmental factors appear and affect business performance on the market. Their nature may be different and therefore they will concern a part of an economic activity. Entrepreneurs should also bear in mind that the environment is constantly changing. It means that one known factor cannot be considered as fixed and stable. For example once there has been a shift in technology that concerns a company's production or some activities on the market, the company should acquire information about this technology and consider the cost of its implementation or the cost of not implementing it. It is also important to prepare a careful analysis of the macroenvironment, as it depends on region, country, and place in general - business influence factors may differ and have a different impact on business. Moreover even if a business has the knowledge that some factor might be changed in the near future, it might be difficult to predict what changes it will bring and in what extent it will affect the enterprise. According to the assumption that an enterprise is like a black box through which various signals pass through, even if some of these signals are consciously created by some entities (e.g. government in the aspect of shaping economic activity of firms by law enforcement), 
finally reactions might occur that have not been taken into account by anyone, in a sense that neither the entrepreneurs nor the government could have predicted the output (Studnicki-Gizbert, 1980, p. 286).

Marek Matejun and Michał Nowicki have classified a set of internal and external factors determining the company's environment. Among the external factors they mention the following:

1. Environmental complexity, which expresses the number, degree of complexity, and diversity of elements occurring in an external environment. An important dimension of this feature is the interrelationships and relationships between the different rules, dimensions, and levels of environment.

2. Variability determined by the speed and dynamics of changes occurring in the external environment.

3. Uncertainty as a consequence of environmental variability and instability.

4. Contextuality of conditions, expressed as a necessity to consider the environment of an organisation as always linked to specific rules that occur in time and space (Matejun \& Nowicki, 2013, pp. 153-154).

An organisation that takes into account the above factors has better environmental accommodation. Organisations can improve it by the continuous process of identifying the specific environment features, namely (Wach, 2008, pp. 58-59):

a) observation of the environment, observation effectiveness depends to a large extent on the methods and techniques used in environmental measurement studies;

b) a description of the environment, which is a presentation of its characteristics, which may take into account the different range of details of the criteria for its structuralization;

c) recognition of the environment's characteristics, which is a set of distinguishing properties of a given environment;

d) a characteristic segregation, which means scheduling logical attributes to specific classes;

e) typology refers to appropriate environment type.

The macroenvironment is complex, dynamic, and far-reaching, therefore companies should continuously analyse the external forces and factors. Also their connections and relations with the company should be the subject of analysis. The importance of this issue is provided by the following arguments: 1) the environment determines 
opportunities and threats - this is why firms should be prepared to change threats to opportunities or at least bear less costs; 2) seizing opportunities can lead to expanding the current economic activity; 3) entities, especially their workers, have to continuously update their knowledge; 4) when it is possible for a company to adapt to the approaching change, it can build in that way a positive image and send signals to microenvironment entities that the company is flexible and sensitive in the aspects of development; 5) everything above can help the company to be ahead of the competition - knowing the conditions of the environment, reacting faster or at least at the same time; 6) a proper analysis and appropriate adaptive activities can help to identify and correct a company's weaknesses and to improve its strengths. All of the above-mentioned activities are necessary and create invaluable opportunities on the market only when circumstances of the environment are predictable, at least to some extent.

\section{ASPECTS OF LEGAL ENVIRONMENT}

Legal environment is a set of legal aspects as follows: 1) law and regulations that influence business activity on the market (e.g. companies law, competition law) and within an organisation (e.g. labour law, accounting and tax law); 2) provisions of the Constitution (general rules and principles that the government in the name of all society considers as the most important and worth to implement and enforce; also rights and duties in related to citizens); 3) justice activity (especially activity of civil justice, as the courts investigate cases that are either related to trade or directly affect business). It may be stated that the rule of law connects all the above-mentioned legal aspects of businesses activity.

When concerning the rule of law principle it is always a question of material and formal guaranties properly functioning in a state. Formal guaranties, in other words institutional, are considered as mechanisms for monitoring compliance with the law by the state in the course of its regulation and application. It means that the government and its institutions ought to make decisions in accordance with the valid law and in a manner determined by the law (Leszczyński, 1989, p. 56). Material guaranties correspond to economy (e.g. economic system, economic development) and social factors adequate to the society within the state borders. It may be stated that material guaranties are like 
the muscles, tissue, and blood vessels on a skeleton made of formal guaranties. Some features are given and it is hard to change them in a short perspective, but it is crucial to follow the direction that will continuously shape the state's condition. In a state where the rule of law is of high quality, the basic premises of law include: separation of powers, constitutionalism, legality, primacy of the law, prohibition of retroactivity, allowing interference with liberty and property units exclusively on the basis of statutory authorisation, judicial review of executive actions, and liability for damage done by the state or its officials (Skrzydło, 2003, p. 109). In other words, the state ought to manage in accordance with the law, with respect to the principle that the law is above the state, that the law establishes guidelines of the state and the society's actions.

The legal environment can be also considered in an international dimension. All national legislators are confronted with a global legal environment in which authoritative rulemaking, rule enforcement, and processes of dispute resolution occur. In the definition presented by Shavana Musa and Eefje de Volder the global legal environment refers to a multi-layered phenomenon which includes all mechanisms of authoritative rulemaking, rule enforcement, and dispute resolution that transcend national borders. It emerges out of the actions of both public and private legal actors, the ideas and research of legal scholars, and the initiatives and actions of international institutions. Even though national legislators' behaviour influences the global legal environment, it emerges to a large extent without being directed (Musa \& de Volder, 2013).

The legal environment is permanently changing. The rate of changes is not comparable to other environmental areas, but still it is possible to mark changes and observe the influence on other aspects. For ages states either by unions and organisations or by force have been creating new legal perspectives for its citizens. Nowadays, not much has changed. New organisations are created, especially those with an economic nature have a considerable impact on business life among states that are part of the organisation. For instance European Union legislation affects more and more areas of business. At the beginning of its existence it started with steel, coal, and atom energy regulations. Now the EU can state that a carrot is a fruit or a snail is a fish and it can also forbid product and service discrimination by discriminating other products or services (C-120/78, Cassis de Dijon). 
The rule of law concept functions as a complex, multi-component historical idea with a large rhetorical power. Its fundamental meaning corresponds to the postulate of stable law which is known by its recipients even before its implementation. In this sense, the rule of law is distinguished by the following features: 1) it protects against anarchy; 2) it allows people to organise their affairs and interests with reasonable certainty, that they can plan in advance the legal consequences of their actions; 3) it protects against at least some manifestations of official arbitrariness. It may be stated that the rule of law principle works when: 1) citizens are able to understand the law and observance rules; 2) the law should be effective and efficient; 3) legal institutions are more important than discretionary decisions; 4) adjudication in matters of impartial and non-party judges (Fallon, 1997, pp. 3-8).

The World Justice Project, an independent, multidisciplinary organisation, works to globally advance the rule of law. In the meaning presented by the WJP the rule of law is a set of four elements forming a coherent legal state structure. This coherence is built through consistent compliance with the following principles:

1. Government and its officials and agents (governmental organizations) as well as individuals and private entities are accountable under the law.

2. Rights are transparent, clear, published, stable, and on-deleterious. Fundamental human rights are protected. The right to security and ownership are the foundation of protection.

3. The process of passing the law is accessible, equitable, fair, and effective.

4. The administration of justice operates smoothly and without delay. It is managed by competent, ethical, and independent representatives, whose number is sufficient. They have adequate resources and represent the interests of the communities they serve (worldjusticeproject.org).

The principle of the rule of law concerns various aspects of the state's functioning - in particular:

1. Constraints on government powers - measures the extent to which those who govern are bound by law. It comprises the means, both constitutional and institutional, by which the powers of the government and its officials and agents are limited and held accountable under the law (this factor measures if: 
1) government powers are effectively limited by the legislature;

2) government powers are effectively limited by the judiciary;

3) government powers are effectively limited by independent auditing and review; 4) government officials are sanctioned for misconduct; 5) government powers are subject to non-governmental checks; 6) transition of power is subject to the law).

2. Absence of corruption - is measured in a number of government agencies. The factor considers three forms of corruption: bribery, improper influence by public or private interests, and misappropriation of public funds or other resources (this factor measures if government officials in: 1) the Executive Branch do not use public office for private gain; 2) the judicial branch do not use public office for private gain; 3) the police and the military do not use public office for private gain; 4) the legislative branch does not use public office for private gain).

3. Open government - is defined as a government that shares information, empowers people with tools to hold the government accountable, and fosters citizen participation in public policy deliberations. It measures if: laws and data are publicised, there is a right to information, civic participation and if there are complaint mechanisms.

4. Fundamental rights protection - recognises a system of positive law that fails to respect core human rights established under international law is at best "rule by law", and does not deserve to be called a rule of law system (this factor measures if there is: 1) equal treatment and absence of discrimination; 2) effectively guaranteed right to life and security of a person; 3 ) due process of law and rights of the accused; 4) effectively guaranteed freedom of opinion and expression; 5) effectively guaranteed freedom of belief and religion; 6) effectively guaranteed freedom from arbitrary interference with privacy; 7) effectively guaranteed freedom of assembly and association; 8) effectively guaranteed fundamental labour rights).

5. Order and security - measures how well the society assures the security of persons and property (subfactors' measures if: 1) crime is effectively controlled; 2) civil conflict is effectively limited; 3) people do not resort to violence to redress personal grievances). 
6. Regulatory enforcement - measures the extent to which regulations are fairly and effectively implemented and enforced. Regulations, both legal and administrative, structure behaviours within and outside the government. This factor examines how regulations are implemented and enforced. To facilitate comparisons, this factor considers areas that all countries regulate to one degree or another, such as public health, workplace safety, environmental protection, and commercial activity (subfactors' measures if: 1) government regulations are effectively enforced; 2) government regulations are applied and enforced without improper influence; 3) administrative proceedings are conducted without unreasonable delay; 4) due process is respected in administrative proceedings; 5) the government does not expropriate without adequate compensation).

7. Civil justice factor - measures whether ordinary people can resolve their grievances peacefully and effectively through the civil justice system (subfactors' measures if: 1) people can access and afford civil justice; 2) civil justice is free of discrimination; 3) civil justice is free of corruption; 4) civil justice is free of improper government influence; 5) civil justice is not subject to unreasonable delays; 6) civil justice is effectively enforced; 7) ADRs are accessible, impartial, and effective).

8. Criminal justice - evaluates the criminal justice system. An effective criminal justice system is a key aspect of the rule of law, as it constitutes the conventional mechanism to redress grievances and bring action against individuals for offenses against society (subfactors' measures if: 1) criminal investigation system is effective; 2) criminal adjudication system is timely and effective; 3) correctional system is effective in reducing criminal behaviour; 4) criminal justice system is impartial; 5) criminal justice system is free of corruption; 6) criminal justice system is free of improper government influence; 7) due process of law and rights of the accused) (worldjusticeproject. org/what-rule-law, accessed: $23^{\text {rd }}$ Oct 2017). 


\section{THE IMPORTANCE OF A COMPANY'S LEGAL ENVIRONMENT}

The legal environment is an important part of the reality in which entrepreneurs operate. Like any other environment, it is also complex, variable, and diverse. Many additional forces affect its shape and impact. The forces are shaped by internal conditions - economic, political or social as well as external. The external conditions relate to the country's geopolitical situation, its role and importance in the international arena, and its involvement in international economic and political organisations. The wide spectrum of impact causes the legal environment to be more turbulent than it would be expected by entrepreneurs, forcing them to change and adapt, which does not always seem to be in line with the logic of market functioning. The ability to create reasonable, coherent, and rational law promotes the entrepreneurship development. At the same time an efficient state creates conditions for a stable and effective market exchange.

The rule of law establishes standards that people among a given society must follow to avoid being penalised. The rule of law not only allows people to understand what is expected of them in their personal capacities but also sets forth rules for businesses, so they also know what is and what is not expected while making dealings and transactions. In addition, it restrains government and others from infringing property rights. Whereas disputes arise, the set of rule of law factors provide a direction and means of the solution. It provides guidance and direction in every area of business. For example, it ensures means to bring a complaint against another party to a neutral decision maker, so that a decision can be made regarding the dispute. Because of a given rule of law system, entities know that they are permitted. Or they can try an alternative method of dispute resolution if they do not wish to engage in litigation. This expectation is reasonable only because of the rule of law (Lau \& Johnson, 2014).

It was pointed out that "the rule of law sometimes plays as a Trojan horse to import other political goals such as democracy, human rights, and specific economic policies" (Chesterman, 2008, p. 360). The rule of law also provides protection for property, which is especially important in reference to business and considers protection for intangible property, such as intellectual property - trade secrets, trademarks, or 
copyrights. People would not have the incentive to create or share new intellectual property if they had no reasonable expectation of being able to protect it. And it is also a question of protecting this kind of property by a business by itself having no measures and possibilities to check signals of improper intellectual property usage. Businesses also rely on the rule of law to govern their debtor and creditor relationships (for instance in case of bankruptcy). The rule of law also protects people from businesses' adverse effects. Antitrust legislation is an example that prevents certain anti-competitive practices, such as colluding and price fixing. Additionally, businesses are prohibited from using deceptive advertising and are held responsible when they manufacture or sell defective products that may cause an injury. The rule of law also protects businesses from the government. Since everyone is subject to the law, even government itself may not overextend its reach when regulating or investigating businesses. Moreover, without a rule of law system, people would have to physically protect their own property. This would lead to a breakdown in the social structure, and it would result in vigilante justice and physical strength playing primary roles in dispute resolution (Lau \& Johnson, 2014). It should be noted that the invoked authors presents an idealistic concept of the principle. They describe how the rule of law works in absence of disruptive factors.

A solid understanding of the legal environment can help to avoid liability or at least minimise the risk. For instance marketers must be particularly aware of tort law, consumer protection law, and intellectual property law to avoid charges of libel, those in advertising need to take care not to defame another person, company, or product. It might be tempting to do so, especially if a company was engaged in serious competition with another company that sell a similar product. Additionally, marketers must be aware of other people's intellectual property rights to avoid copyright or trademark infringement in their own work product (Lau \& Johnson, 2014).

The main factors and forces occurring and affecting a company should be analysed and conveyed to opportunities in the future. This approach includes risk analysis. In economics theory, risk is usually defined along with the notion of uncertainty to indicate the significant difference between the two concepts. Uncertainty is not measurable. Some more or less expected events or occurrences might be described but without a possibility of their probability value. Unlike uncertainty, the value of risk can be estimated. Frank H. Knight pointed out that 
"in physics, the model and archetype of an exact science of nature, a relatively small and workable number of laws or principles tell us what would happen if simplified conditions be assumed and all disturbing factors eliminated" (Knight, 1957, p. 4). Economics is not so successful because of the lack of an explicit and clear description of market forces' shifts. General models are developed and described. On their basis other, similar structures are explained with more or less success.

There are some concepts of risk division which consider: market, credit, operating, and legal risk. The last one is in the course of interest of this paper as it strongly associated with the legal environment where a company operates. Its scope is dependent on various external factors and the internal activities of the company. Legal risks may occur in: regulatory instability or changes in jurisdiction lines; erroneous configuration of legal relations; failure or improper use of the law in the organisation; unfavourable decisions of litigation for the organisation. Legal risk is not defined in Polish law or in the EU legislation, its definition is based on the definition of operational risk. The concept is broad and covers the process of law issues' regulation, implementation, and compliance. Therefore, the following types of legal risk may be identified: the risk of over-regulation related to a particular section of social or economic life - limiting economic freedom; the risk of insufficient regulation of the area of socio-economic development - leaving loopholes; the risk of non-applicability in practice related to certain legal regulations; the risk of difficulties in law enforcement. For example the G30 defines legal risk as "the risk of loss because a contract cannot be enforced. This includes risks arising from insufficient documentation, insufficient capacity or authority of a counterparty (ultra vires), uncertain legality, and unenforceability in bankruptcy or insolvency" (The Group of Thirty, 1993, p. 48). The Basle Committee indicates that legal risk occurs when:

1) the existing laws may fail to resolve the legal issues involving a company;

2) a court case involving a particular company may have wider implications for business and involve costs to it and many other companies;

3) laws affecting commercial enterprises may change, especially when entering new types of transactions and when the legal right of a counterparty to enter into a transaction is not established (Basle Committee on Banking Supervision, 1997, p. 22). 


\section{RELATIONS BETWEEN THE LEGAL ENVIRONMENT, QUALITY, AND ECONOMIC FREEDOM}

Economic freedom is the fundamental right of every human being to control his or her own labour and property. In an economically free society, individuals are free to work, produce, consume, and invest. Governments allow labour, capital, and goods to move freely, and refrain from coercion or constraint of liberty beyond the extent necessary to protect and maintain liberty itself. In a market-oriented economy, societal norms, not government laws and regulations, are a priority. Social norms are important, because they reflect history, culture, and the experience of generations learning how to live with one another. They guide the understanding of ethics, the etiquette of personal and professional relationships, or consumer tastes. Democratic political systems, at their best, reflect societal norms in their laws and regulations, but even democratic governments, if unconstrained by constitutional or other traditional limits, may pose substantial threats to economic freedom (heritage.org).

Freedom in business is understood as an ability of an individual to set up and run a business without inappropriate state interference. It is one of the most fundamental indicators of economic freedom. Burdensome and excessive regulations are the most common obstacles to the free conduct of business activity. Rules can create complex and lengthy procedures that will consequently increase production costs, for example by obtaining a specific permit. In some countries, the procedure for getting a business permit is simple and fast, it may involve for instance registration via the Internet at a minimum fee. For example, in Hong Kong obtaining a business license requires completing one form, and the entire process can be completed within a few hours. In other economies such as India and parts of South America, the process of getting a business permit can take much longer and include many meetings with government officials. In addition, two countries with the same regulatory set may impose different regulatory burdens. If one country applies its rules in a uniform and transparent manner, it can reduce regulatory burdens by facilitating long-term business planning. On the other hand, using the regulations improperly, the regulatory burden increases, creating an unpredictable business environment (heritage.org). 
Economists are increasingly aware of the importance of legal institutions - in particular the presence of the rule of law, in creating the foundations of freedom and prosperity. The economies of Eastern Europe and developing countries in Latin America and Africa are looking for tips on how to develop and maintain the rule of law (Zywicki, 2002, p. 1). Todd Zywicki indicates that "the link between the rule of law and economic growth derives from the micro-level incentives created by the conditions sustained by the rule of law. By constraining arbitrary governmental activity, the rule of law provides an institutional framework conducive to investment, entrepreneurship, and long-term capital development" (Zywicki, 2002, p. 22). It is also noticeable that commercial law, built on fair rules which broadens freedom in business, "often receives priority from the government and business due to interest in economic growth and foreign investment" (Voorhoeve, 2007, p. 97).

The rule of law is recognised in law and philosophy as a valuable moral value, primarily for the protection of individuals' freedom. In the literature, authors like Friedrich von Hayek (1960), John Rawls (1999) or Joseph Raz (1979) expressed in similar way the idea of the rule of law. In law the concept has developed a uniform construction, while in economics it is still treated cautiously, although its role in the theory of economic development is noticeable. For example the studies of Stephan Haggard et al. (2008). Among economists' opinions economic development may be linked directly with property rights and contract enforcement (Haggard \& Tiede, 2010, p. 674) which remains a part of the rule of law concept. Robert Barro revealed that the more prosperous regions are more democratic. Moreover he indicates that "the indicator for overall maintenance of the rule of law seemed a priori to be the most relevant for investment and growth" (Barro, 1999, p. 166, 174). He also pointed out that according to the results of his previous empirical work, the rule of law "is an important predictor of economic growth" (Barro, 1996, p. 70).

\section{MATERIAL AND METHODS}

To answer the question if legal factors, understood as the rule of law, affect the freedom in business, the values of the two main indexes were taken into account. The values of the Rule of Law Index, Business 
Freedom, and the GDP value (PPP measured) from 2016 were used in the study. It should be noticed that there are many methods identified to provide data for the rule of law. For instance Svend-Erik Skaaning indicates seven measurement methods and outlines the main differences, which are significantly noticeable mostly in "restrictions in the scope and availability of disaggregate data, insufficient codebooks, and unjustified aggregation procedures" (Skaaning, 2010, p. 449). This highlights some basic problems with the usage of indexes, when collected data may not be creditable. The author does not mention the World Justice Index among the classified methods. Moreover, the World Justice Index was chosen because of its creditability and data quality. It "combines information on de jure provisions and de facto implementation that promote effective regulation from expert surveys" (The Governance Report 2014, p. 142). As for Business Freedom possessed form Economic Freedom Index, Lau and Lam indicate that

the index offers the most comprehensive, concise and up-to-date measurement of the world's economies since its introduction in 1995. It provides a benchmark by which global economic progress and freedom can be tracked and compared. Moreover, the index has been frequently applied to study the relationship among economic freedom, economic growth, economic performance and corruption, for instance in studies of Barro, Chafuen and Guzman or Jenkins (Lau \& Lam, 2002, p. 664).

For further analysis of legal environment quality following data will be used:

1) The Rule of Law Index provided by World Justice Project;

2) The Business Freedom (BF) indicator as part of the Economic Freedom Index (EFI) provided by the Heritage Foundation.

The Rule of Law Index is the source for original data on the rule of law. The 2016 edition expands coverage to 113 countries and jurisdictions (from 102 in 2015), relying on more than 110,000 households and expert surveys to measure how the rule of law is experienced and perceived in practical, everyday situations by the general public worldwide (worldjusticeproject.org/about-us/overview/our-approach, accessed: $10^{\text {th }}$ Dec 2017).

The Economic Freedom Index (EFI) covers ten freedoms, which are property rights, freedom from corruption, fiscal freedom, government spending, freedom in business, labour freedom, monetary freedom, trade freedom, investment freedom, and financial freedom in 186 countries. 
The EFI takes a comprehensive view of economic freedom. Some of the aspects of economic freedom that are evaluated are concerned with a country's interactions with the rest of the world - for example, the extent of an economy's openness to global investment or trade. Most of the subfactors focus on policies within a country, assessing the liberty of individuals to use their labour or finances without undue restraint and government interference. Each of the measured aspects of economic freedom plays a vital role in developing and sustaining personal and national prosperity. All are complementary in their impact, however, and progress in one area is often likely to reinforce or even inspire progress in another (heritage.org). For analysis of legal environment quality only the Business Freedom component was selected and compared with the Rule of Law Index.

The Business Freedom measures the extent to which the regulatory and infrastructure environments constrain the efficient operation of businesses. The quantitative score is derived from an array of factors that affect the ease of starting, operating, and closing a business. The Business Freedom score for each country is a number between 0 and 100, with 100 indicating the freest business environment. The score is based on 13 subfactors, all of which are weighted equally, using data from the World Bank's Doing Business report. The mentioned subfactors include the following: starting a business - procedures (number), starting a business - time (days); starting a business - cost (\% of income per capita), starting a business - minimum capital (\% of income per capita), obtaining a license - procedures (number), obtaining a license - time (days), obtaining a license - cost (\% of income per capita), closing a business - time (years), closing a business - cost (\% of estate), closing a business - recovery rate (cents on the dollar), getting electricity - procedures (number), getting electricity - time (days) and getting electricity - cost (\% of income per capita) (Miller et al., 2018, p. 458).

The analysis was conducted for data uniformed for 97 countries which were covered by both indexes for the year 2016 .

Figure 1 presents the values for Business Freedom and the Rule of Law in 2016 for all 97 countries. Business freedom data have the scope of values between 0 and 100, and Rule of Law Index data have the scope of values between 0 and 1 . Points which differ the most from all point population are described in the figure. The leader in the considered issue is Denmark, the last is Cambodia and Venezuela. Cambodia 
has poor values in both BF and the Rule of Law and Venezuela is an example, where the Rule of Law value is low, but at the same time BF is relatively high. Similar situation can be noticed for the example in Egypt. At the same time in Venezuela trade freedom value slightly rose by 0.4 in comparison to 2015 , even with the inflation rate at the level of $62.2 \%$. Other factors taken into consideration by the EFI decreased. A relation can be noticed between the Rule of Law level and Business Freedom - in general the higher BF is the higher is the Rule of Law.

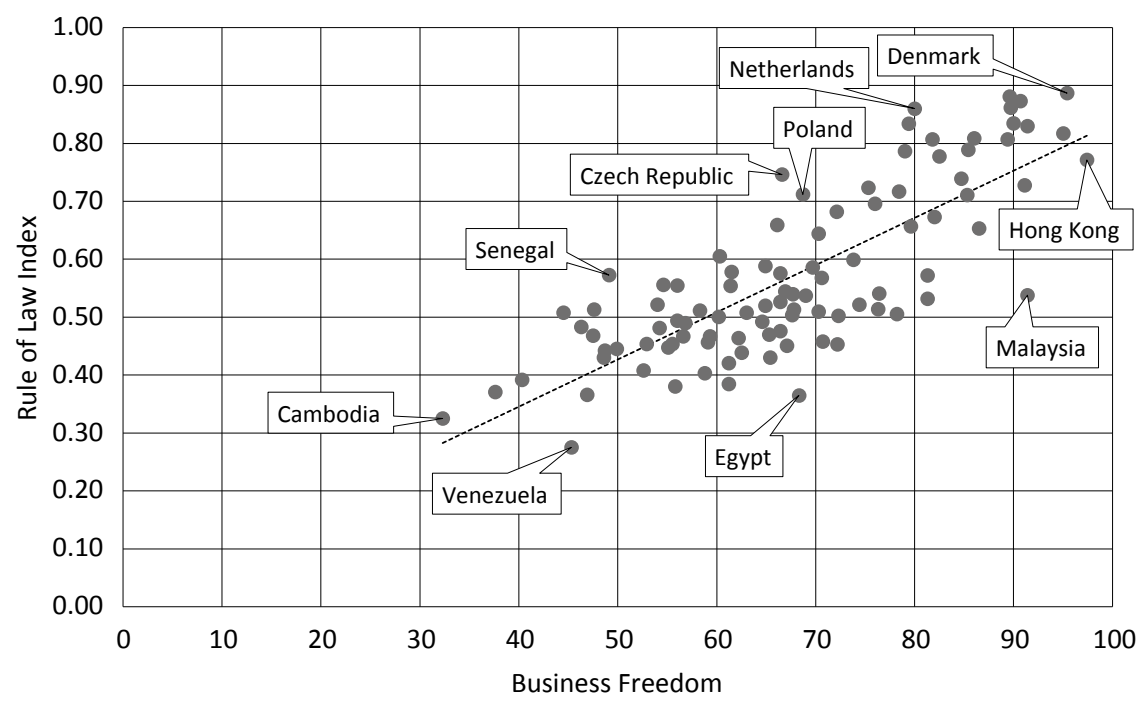

Figure 1. Business Freedom and Rule of Law Index values in 2016

Source: own elaboration on the basis on WJP and EFI data.

The example of Venezuela initiated the examination of countries described in Figure 1 as points, which value differ the most from other values of the mainstream in the population. The analysis showed that countries above the mainstream - Senegal, the Czech Republic, the Netherlands, and Denmark achieved best values in the Rule of Law factor range. In the Netherlands and Denmark, where democracy values are quite strong with a sufficient GDP level, the ranks of the Rule of Law subfactors are more or less at the same level as the overall Index score. In other cases two top peaks in values may be noticed, namely in absence of corruption and order and security. There are also two bottom peaks. In the analysed cases these concern open government 
and regulatory enforcement factors. The Rule of Law Index, the Economic Freedom Index, and the Business Freedom subfactor have similar trend lines. In Venezuela, Egypt, and Malaysia the Business Freedom values are much higher than the Rule of Law values, but the trend is comparable. The analysed cases indicate that countries develop different values with a different time scope. It may be useful to compare future data with a wider timescale for these countries and notice how values evolve.

Table 1. Rule of Law and Business Freedom values analysis in selected countries

\begin{tabular}{|c|c|c|c|c|c|c|c|c|c|}
\hline & & $\begin{array}{l}\frac{\pi}{0} \\
\stackrel{0}{0} \\
\stackrel{0}{0} \\
>\end{array}$ & 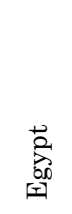 & 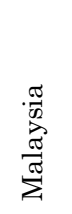 & 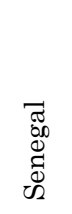 & 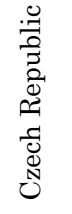 & 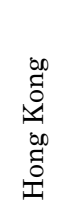 & 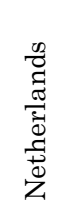 & 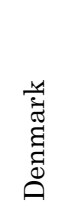 \\
\hline \multirow{9}{*}{ 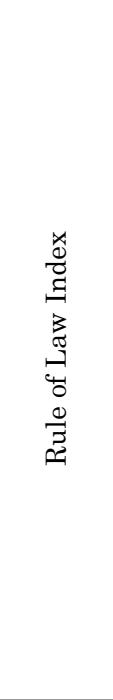 } & Overall Index score & 0.28 & 0.37 & 0.54 & 0.57 & 0.75 & 0.77 & 0.86 & 0.89 \\
\hline & $\begin{array}{l}\text { Factor 1: constraints } \\
\text { on government } \\
\text { powers }\end{array}$ & 0.18 & 0.31 & 0.50 & 0.67 & 0.76 & 0.70 & 0.89 & 0.93 \\
\hline & $\begin{array}{l}\text { Factor } 2 \text { : absence } \\
\text { of corruption }\end{array}$ & 0.25 & 0.45 & 0.61 & 0.55 & 0.68 & 0.85 & 0.88 & 0.96 \\
\hline & $\begin{array}{l}\text { Factor 3: open } \\
\text { government }\end{array}$ & 0.32 & 0.23 & 0.35 & 0.52 & 0.69 & 0.66 & 0.85 & 0.86 \\
\hline & $\begin{array}{l}\text { Factor 4: } \\
\text { fundamental rights }\end{array}$ & 0.33 & 0.29 & 0.44 & 0.62 & 0.81 & 0.70 & 0.86 & 0.92 \\
\hline & $\begin{array}{l}\text { Factor } 5 \text { : order } \\
\text { and security }\end{array}$ & 0.48 & 0.49 & 0.82 & 0.67 & 0.89 & 0.89 & 0.85 & 0.92 \\
\hline & $\begin{array}{l}\text { Factor 6: regulatory } \\
\text { enforcement }\end{array}$ & 0.21 & 0.33 & 0.47 & 0.56 & 0.68 & 0.80 & 0.88 & 0.85 \\
\hline & Factor 7: civil justice & 0.29 & 0.38 & 0.56 & 0.57 & 0.73 & 0.77 & 0.88 & 0.84 \\
\hline & $\begin{array}{l}\text { Factor 8: criminal } \\
\text { justice }\end{array}$ & 0.13 & 0.43 & 0.56 & 0.43 & 0.73 & 0.80 & 0.80 & 0.82 \\
\hline \multirow{2}{*}{ 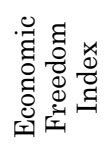 } & Overall Index score & 33.7 & 56.0 & 71.5 & 58.1 & 73.2 & 88.6 & 74.6 & 75.3 \\
\hline & Business Freedom & 45.3 & 68.3 & 91.4 & 49.1 & 66.6 & 97.4 & 80 & 95.4 \\
\hline
\end{tabular}

Source: own elaboration on the basis on the WJP and EFI data.

Figure 2 presents European and North American countries. In general all of the examined countries in this group tend to maintain the rule where a higher $\mathrm{BF}$ value indicates a higher value of the Rule 
of Law. Countries with top ranks of both indexes are the following: Denmark, Finland, Norway, Sweden, Germany, the United Kingdom, Belgium, the Netherlands, Austria, Canada and the United States. It is a striking fact that the position of Bulgaria (a European Union member) is almost equal to Belarus' position. The trend line is about a 45 degree inclination. This indicates the fact that when the Business Freedom index rises then the Rule of Law values rise as well. Values of both indexes grow symmetrically. Probably, an in-depth examination considering economic development could give more suitable and satisfying information.

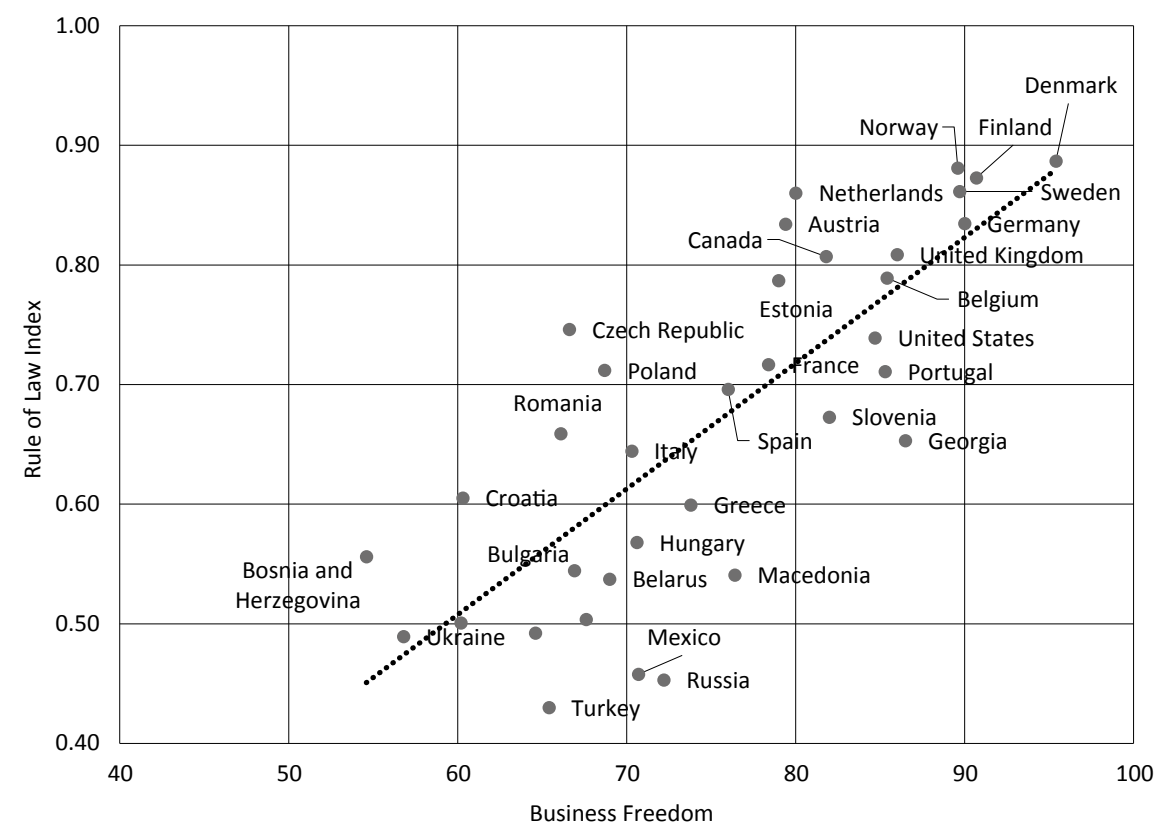

Figure 2. Business Freedom and Rule of Law Index in Europe and North America in 2016

Source: own elaboration on the basis of the WJP and EFI data.

Figure 3 presents the Business Freedom and the Rule of Law values for Asia-Pacific countries. Countries can be divided into two groups. The higher rank group consist of New Zealand, Singapore, Australia, Japan, Hong Kong, and the Republic of Korea, which are generally more developed in an economic sense than other countries in the region. Whereas, the lower circle group includes the following countries: Bangladesh, 
China, India, Indonesia, Kazakhstan, the Kyrgyz Republic, Mongolia, Nepal, Pakistan, Philippines, Sri Lanka, Thailand, Uzbekistan, and Vietnam. As interesting examples Malaysia and Thailand may be considered, which have a relatively high score of Business Freedom, - 91.4 and 76.3 respectively with the Rule of Law at the level of 0.54 and 0.51. For example China's economic growth benefited a lot from the economic openness of the market approach (Wang, 2012, p. 39).

The material improvement of the well-being of the Asia-Pacific inhabitants depends to a large extent on the economic growth maintenance. This purpose will be achieved when there are coordinated actions in both micro- and macroeconomic policy. There is a need for conditions that facilitate creation of enterprises and new working places, as well as the development of the business environment and, to achieve better export and import conditions. Economic development should not be a goal itself. More important is the proper use of law as a tool for socio-economic development (Salevao, 2005, p. 27).

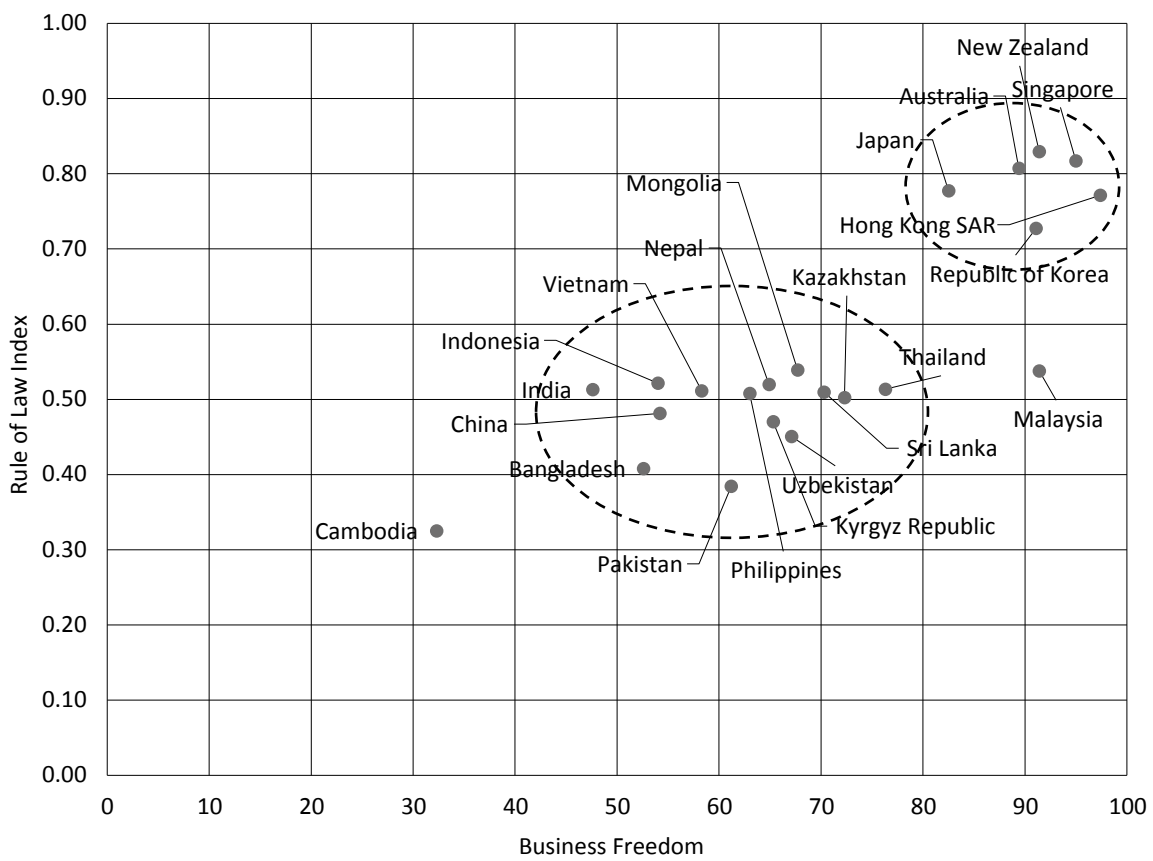

Figure 3. Business Freedom and World Justice Index in the Asia-Pacific region in 2016

Source: own elaboration on the basis of the WJP and EFI data. 
It was assumed in the hypothesis that there may be a connection between legal environment quality and a country's economic development. For further analysis the notion of economic development will be identified with a country's GDP (given in billions of USD, PPP). Figure 4 presents the Rule of Law Index in combination with the gross domestic product in 2016 for 97 countries (the same sample as for the previous studies). It may be noticed that the trend line is rising - when the Rule of Law Index rises the GDP values also rise.

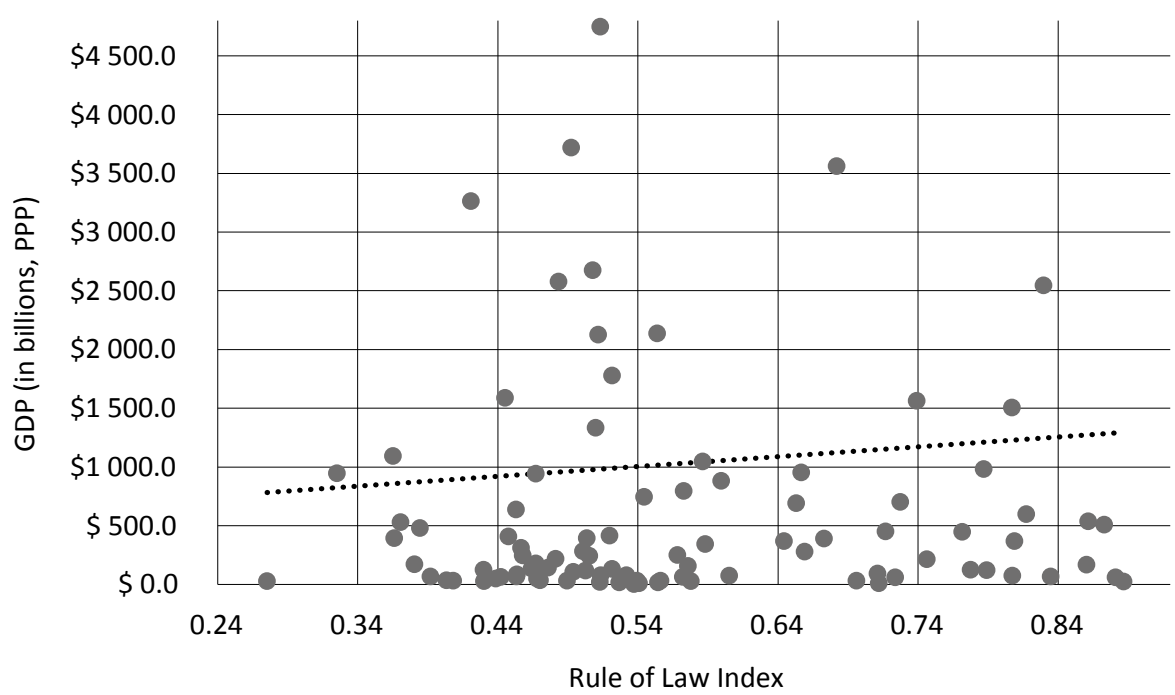

Figure 4. GDP and Rule of Law values in 2016

Source: own elaboration on the basis of the WJP and EFI data.

A connection between the Business Freedom and the GDP values may also be noticed. It may be stated that both factors - Rule of Law and Business Freedom are highly desirable for a country's better development.

Additionally, a factor analysis was conducted. Factor analysis is a method of analysing the covariate of variables of a various nature, for example: psychological, economic, or social. In the present example, legal and economic factors were analysed in order to detect specific factors and their correlation. At the beginning, all subfactors from the EFI were examined with the Rule of Law Index value. During the analysis some subfactors were deleted (e.g. government spending, labour freedom), as 


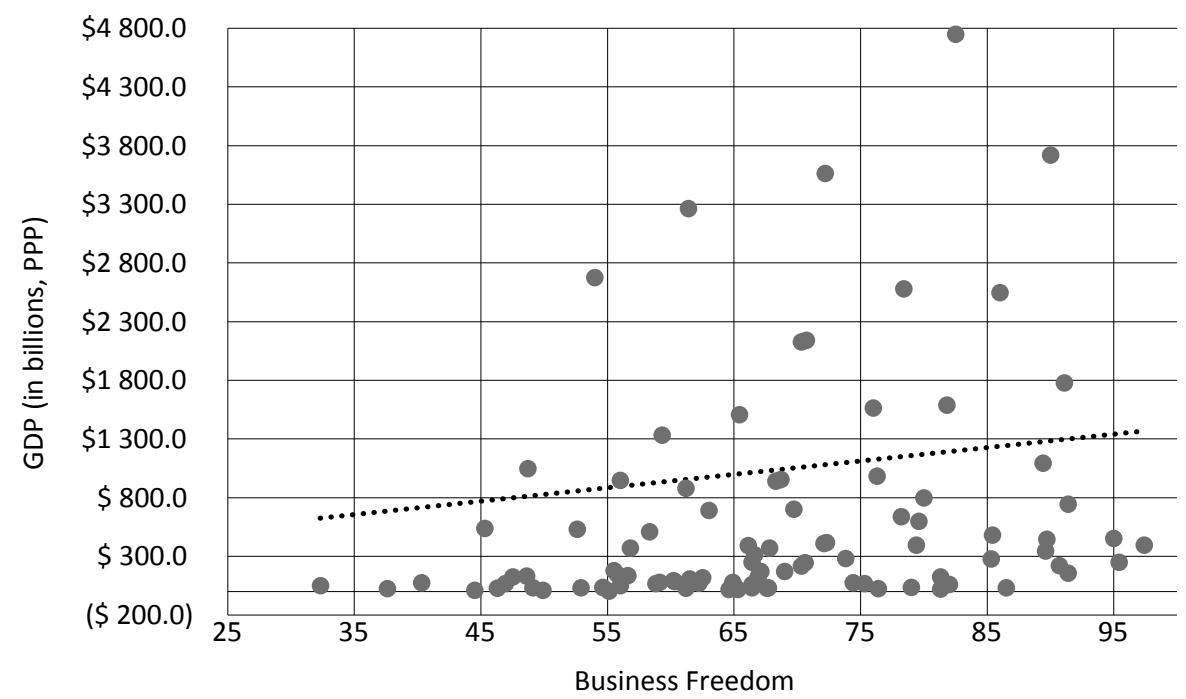

Figure 5. GDP and Business Freedom Index values in 2016

Source: own elaboration on the basis of the WJP and EFI data.

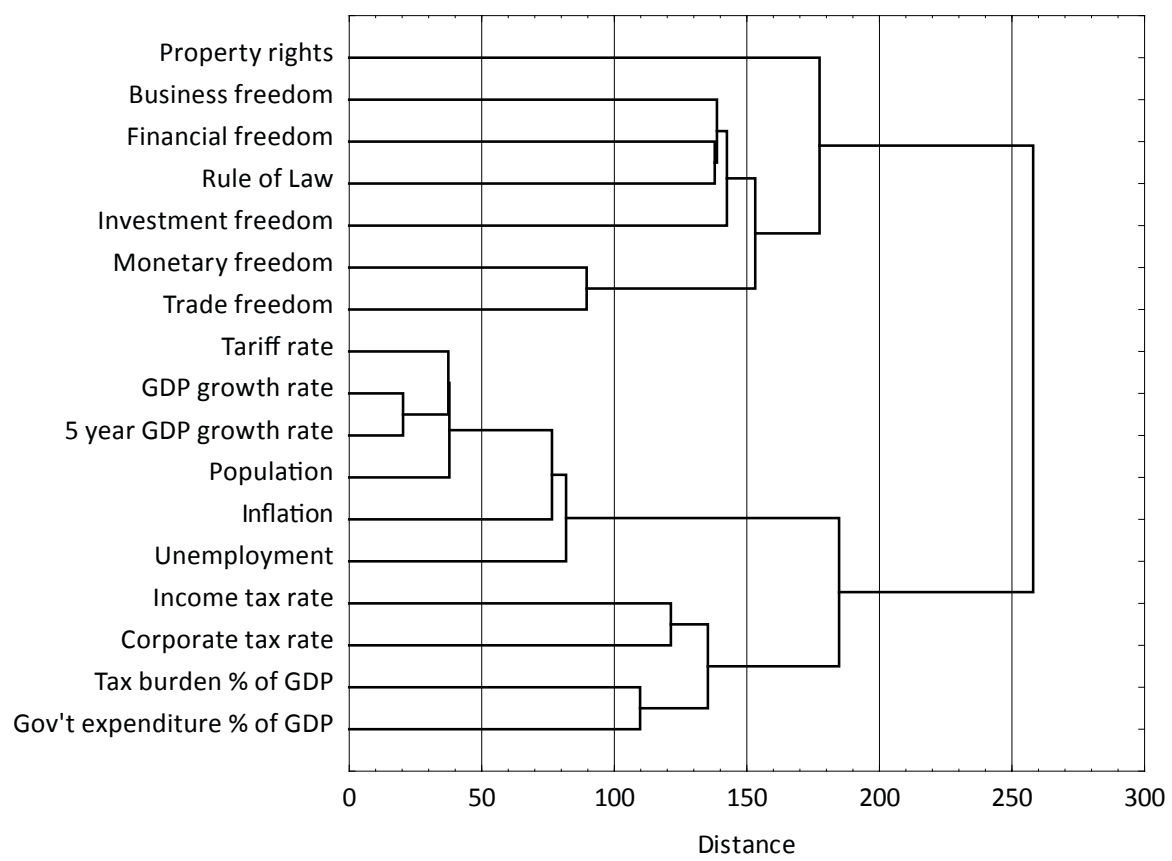

Figure 6. The Rule of Law and Business Freedom factor analysis

Source: own elaboration on the basis of the WJP and EFI data. 
it was noticeable that their connection with other subfactors is inconsiderable and therefore does not give satisfactory conclusions. Other subfactors were formulated into two groups. The first group contains: tariff rate, GDP growth rate, 5-year GDP growth rate, population, inflation, and unemployment. These are strictly connected. The second group focuses on: income tax rate, corporate tax rate, tax burden $\%$ of GDP, and government expenditure \% of GDP. Third group consists of property rights, Business Freedom, financial freedom, Rule of Law, investment freedom, monetary freedom, and trade freedom. Connections in this group indicate that the Rule of Law and Business Freedom are very close related. Moreover trade freedom, which is essential for open economy, is also important. This was presented in the Figure 6.

\section{CONCLUSIONS}

The main goal of the research was to analyse the legal environment considered as the rule of law with its interference with freedom in business and gross domestic product. On the basis of the conducted research it may be stated that this impact is significant. The in-depth analysis of countries in Europe, North America, and Asia-Pacific also confirmed this relation. It was also noticed that in countries where freedom in business is wider, usually the level of economic development in a given country is higher and mostly the Rule of Law Index is higher. The conducted factor analysis confirmed a strong relation between the Rule of Law and Business Freedom.

Anthony Downs indicates that a certain country consists of people who have the same preferences and similar views on appropriate goals in life for individuals and for society as a whole. People are free from egoism, which means that personal, own preference does not significantly exceed the preferences of others. Society is then economically organised in a highly specialised division of labour, and lives in a world with a normal level of uncertainty and the cost of access to information (Downs, 1962, p. 2). In reference to the presented data it may be stated that the higher level of Business Freedom and the Rule of Law indicates at what level of economic and legal awareness the examined societies are. There is no doubt that this awareness, which concerns two of most important business's environments, is crucial and determines the course of economic and legal development. 


\section{REFERENCES}

Basle Committee on Banking Supervision (1997). Core Principles for Effective Banking Supervision. Basle, https://www.bis.org/publ/bcbs30a.pdf (accessed: $10^{\text {th }}$ Dec 2017).

Barro, R.J. (1996) Determinants of economic growth: A cross-country empirical study. National Bureau of Economic Research, Working Paper 5698.

Barro, R.J. (1999) Determinants of democracy. Journal of Political Economy, 107(S6).

Chesterman, S. (2008) An international rule of law? The American Journal of Comparative Law, 56(2).

Downs, A. (1962) The public interest: It's meaning in a democracy. Social Research, $29(1)$.

Fallon, R.H. (1997). "The Rule of Law" as a concept in constitutional discourse. Columbia Law Review, 97(1).

The Governance Report 2014, The Hertie School of Governance, OUP Oxford.

von Hayek, F. (1960). The Constitution of Liberty. Chicago University of Chicago Press,.

Haggard, S. \& Tiede, L. (2010). The rule of law and economic growth: Where are we? World Development, 39(5).

Haggard, S., MacIntyre, A., \& Tiede, L. (2008). The rule of law and economic development. Annual Review of Political Science, 11.

Kotler, P. (2005). Marketing, B. Pilarczyk \& H. Mruk (eds.), R. Bartołd et al. (transl.). Poznań, Rebis.

Knight, F.H. (1957). Risk, Uncertainty and Profit. New York: Kelley and Millman.

Lau, T. \& Johnson, L. (2014). The Legal and Ethical Environment of Business, v. 2.0. FlatWorld.

Lau, K.-N. \& Lam, P.-Y. (2002). Economic freedom ranking of 161 countries in year 2000: A minimum disagreement approach. The Journal of the Operational Research Society, 53(6).

Leszczyński, L. (1989). Praworządne stosowanie prawa a klauzule generalne. Państwo i Prawo, 11.

Matejun, M. \& Nowicki, M. (2013). Organizacja w otoczeniu - od analizy otoczenia do dynamicznej lokalizacji. In: Adamik A. (ed.), Nauka o organizacji. Ujęcie dynamiczne (pp. 152-221). Warszawa: Oficyna a Wolters Kluwer business.

Miller, T., Kim, A.B., \& Roberts J.M. (2018), Index of Economic Freedom 2018, The Heritage Foundation, https:/www.heritage.org/index/pdf/2018/book/ index_2018.pdf (accessed: 10 $0^{\text {th }}$ Dec 2017)

Musa, S. \& de Volder, E. (2013). Reflections on Global Law. Leiden: Nijhoff. 
Rawls, J. (1999). A Theory of Justice. New York: Harvard University Press.

Raz, J. (1979). The Authority of Law: Essays on Law and Morality. New York: Oxford University Press.

Salevao, I. (2005). The rule of law: Principles, issues and challenges. In: I. Salevao, Rule of Law, Legitimate Governance \& Development in the Pacific. Canberra: ANU E Press.

Skaaning S.-E. (2010). Measuring the rule of law. Political Research Quarterly, 63(2). Skrzydło, W. (ed.) (2003). Polskie prawo konstytucyjne. Lublin: Verba.

Studnicki-Gizbert, K.W. (1980). Towards a general theory of economic regulation. International Journal of Transport Economics, 7(3).

Voorhoeve, J. (2007). From War to the Rule of Law: Peace Building after Violent Conflicts. Amsterdam: Amsterdam University Press.

Wach, K. (2008). Identyfikacja i strukturalizacja cech otoczenia przedsiębiorstw. Organizacja i Kierowanie, 1.

Wang, X. (2012). Economic growth over the past twenty years. In: R. Garnaut \& L. Song (eds.), China: Twenty Years of Economic Reform. Canberra: ANU Press.

Zywicki, T.J. (2002) The rule of law, freedom, and prosperity. Supreme Court Economic Review, 10.

heritage.org

worldjusticeproject.org

worldjusticeproject.org/about-us/overview/our-approach (accessed: 27 $7^{\text {th }}$ Oct 2017)

worldjusticeproject.org/what-rule-law (accessed: $23^{\text {rd }}$ Oct 2017) 


\title{
JAKOŚĆ OTOCZENIA PRAWNEGO I JEGO POWIAZZANIA Z WOLNOŚCIA W BIZNESIE
}

\begin{abstract}
Abstrakt
Tło badań. Otoczenie prawne, rozumiane jako zespół czynników oddziałujących na przedsiębiorstwa w danym kraju, odgrywa dużą rolę w otoczeniu przedsiębiorstw.

Cel badań. Głównym celem prowadzonych badań jest weryfikacja hipotezy o istotności otoczenia prawnego w odniesieniu do wolności prowadzania działalności gospodarczej $\mathrm{w}$ danym kraju oraz osiaganego tam PKB.

Metodologia. Cel badań zrealizowano dzięki wykorzystaniu wartości Rule of Law Index, Economic Freedom Index oraz Business Freedom (stanowiącego subczynnik EFI), a także wartości PKB dla 97 krajów, które w roku 2016 zostały ujęte w klasyfikacji Rule of Law oraz Economic Freedom. Zastosowano metodę porównawcza oraz analizę czynnikową.
\end{abstract}

Kluczowe wnioski. Wyższy poziom praworządności związany jest z wyższym rozwojem gospodarczym i zapewnia większą swobodę biznesowa. W badanych przypadkach w grupie krajów wiodaccych znalazły się: Singapur, Australia, Nowa Zelandia, Dania i Norwegia. Indeksy Rule of Law oraz Business Freedom znajdowały się w tych przypadkach na najwyższych poziomach w odniesieniu do badanej populacji.

Słowa kluczowe: otoczenie biznesowe, otoczenie prawne, praworządność, wolność gospodarcza. 